\title{
Explanation of the Apparent Association of Host Specificity Determinants with $f^{+} \mathbf{R}$ Factors
}

\author{
By DIANE BANNISTER* \\ MRC Molecular Genetics Unit, Department of Molecular Biology, \\ University of Edinburgh, Mayfield Road, Edinburgh, EH9 $3 \mathrm{JR}$
}

(Accepted for publication I2 February 1970)

\section{SUMMAR Y}

Two strains of Escherichia coli $\mathrm{K}$ I 2 carried R factors associated with the hsII host specificity determinants although they were apparently $f^{+}$, while all other $\mathbf{R}$ factors carrying this host specificity have been found to be $f^{-}$. When these two strains were used as donors of drug resistance, separation of two $\mathbf{R}$ factors from each strain was observed. The separated $\mathbf{R}$ factors were tested for $f i$ character, and it was found that in both cases the original strains carried an $f^{+}$and an $f^{-} \mathbf{R}$ factor, and it was the $f^{-} \mathrm{R}$ factor which carried the hsII determinants.

\section{INTRODUCTION}

Transmissible drug resistance in the Enterobacteriaceae is determined by drug resistance factors ( $\mathrm{R}$ factors) which are divisible into two classes, $\mathrm{fi}^{+}$and $\mathrm{fi}^{-}$, on the basis of the repression of the expression of the sex factor F (see Watanabe, 1963), as well as by the structure of their sex pili (see Meynell, Meynell \& Datta, I968). An apparent third, distinguishing feature between the $f i^{-}$and $f^{+} \mathbf{R}$ factors, was that the presence of certain $f^{-} \mathrm{R}$ factors led to a reduction in efficiency of plating (e.o.p.) of a number of bacteriophages such as $\lambda$ and T I (Watanabe, Takano, Arai, Nishida \& Sato, I966).

In a survey of $\mathrm{I} 53 \mathrm{R}^{+}$Escherichia coli $\mathrm{K} \mathrm{I} 2$ strains this affect was observed with both $\mathrm{fi}^{-}$and $\mathrm{fi}^{+} \mathbf{R}$ factors (Bannister \& Glover, 1968). In some instances, a reduction in e.o.p. may be due to the operation of a host-controlled modification, the host range of a bacteriophage being altered by a single cycle of growth in a new host strain (Luria, I953; Arber \& Dussoix, 1962). In I2 $\mathrm{R}^{+}$strains, the reduction in e.o.p. of a number of bacteriophages was found to be due to $\mathrm{R}$ factor-associated host controlled modification, and two different host specificities were observed. One of these, termed hsI, was present only in one $\mathrm{R}^{+}$strain, carrying the $f^{+} \mathrm{R}$ factor $\mathrm{R} 124$, while the second, hsII, was found in the remaining II strains (Bannister \& Glover, I968), and was also shown to be identical to that found in two strains with $f^{-} \mathrm{R}$ factors by Watanabe et al. (1966). Careful examination of the $f i$ character of the II hsII+ strains showed that two of them were apparently exceptional in that they carried $f^{+} \mathbf{R}$ factors. This paper presents the results of an investigation of these two strains.

* Present address: Nuffield Unit of Medical Genetics, Department of Medicine, The University of Liverpool, P.O. Box 147, Liverpool, L69 3 BX. 


\section{METHODS}

Media. The media have been described previously (Bannister, 1970; Bannister \& Glover, 1970).

Antibiotics. Tetracycline: (achromycin hydrochloride from Cyanamid of Great Britain, Bush House, London, W.C.2) used at a final concentration of $50 \mu \mathrm{g} . / \mathrm{ml}$. Streptomycin: (streptomycin sulphate BP from Glaxo Laboratories Ltd., Greenford, Middlesex) used at a final concentration of $20 \mu \mathrm{g} . / \mathrm{ml}$. Sulphonamide: (sulphamezathine from ICI Pharmaceuticals Division, Macclesfield, Cheshire) used at a final concentration of $20 \mu \mathrm{g} . / \mathrm{ml}$. Chloramphenicol: (chloromycetin from Parke Davis, Hounslow, Middlesex) used at a final concentration of $20 \mu \mathrm{g} . / \mathrm{ml}$. Kanamycin: (kanamycin sulphate from Bayer Products Co., Surbiton, Surrey) used at a final concentration of $20 \mu \mathrm{g} . / \mathrm{ml}$.

Bacterial strains: The following Escherichia coli strains were used: c600 thr leu thi lac (Appleyard, 1954) from the collection of Dr S. W. Glover, and J5-3 pro met (Clowes \& Rowley, 1954), J 5-3 $\mathrm{F}^{+}$and J 5-3 $\mathrm{R}^{+}$strains kindly provided by Dr Elinor Meynell and Dr Naomi Datta.

Bacteriophages. Phage $\lambda$ vir (Jacob \& Wollman, 1954); MS 2 (Davis, Strauss \& Sinsheimer, I96I); $\mathrm{T}_{3}$.

Techniques. These are described elsewhere (Bannister, 1970; Bannister \& Glover, I970).

\section{RESULTS AND DISCUSSION}

Association of hsII with the $f^{-}$character. Two strains apparently carrying $f^{+} \mathrm{R}$ factors associated with hsII were examined J5-3 (R 269), which was resistant to the following antibiotics; tetracycline (Tc), streptomycin ( $\mathrm{Sm})$, sulphonamide (Su), and kanamycin $(\mathrm{Km})$; and J5-3 (R 348), resistant to Tc, Sm, $\mathrm{Km}$ and chloramphenicol $(\mathrm{Cm})$. These two strains were used as donors of drug resistance to $\mathrm{c} 600$, and exconjugants selected for one resistance were scored for the others, and for the presence of the hsII determinants. The results of two such experiments are presented in Table I. With R 269, three classes of exconjugants were observed: those resistant to Tc, Sm, $\mathrm{Su}$ and $\mathrm{hsII}^{+}$; those resistant to $\mathrm{Tc}, \mathrm{Sm}, \mathrm{Su}, \mathrm{Km}$ and $\mathrm{hsII}^{+}$, and those resistant to $\mathrm{Sm}, \mathrm{Su}, \mathrm{Km}$ and not carrying the hsII determinants. The most likely explanation of these findings is that two $R$ factors were present in the original strain, one carrying resistance to $\mathrm{Tc}, \mathrm{Sm}, \mathrm{Su}$ and $\mathrm{hsII}^{+}$determinants, and the other carrying resistance to $\mathrm{Sm}, \mathrm{Su}$ and $\mathrm{Km}$. Those exconjugants carrying all the determinants of the parent strain would then arise by transfer of both $\mathrm{R}$ factors to the recipient. Similarly, three types of exconjugant were found for $\mathrm{R} 348$ : those resistant to Tc, Sm and hsII ${ }^{+}$; those resistant to $\mathrm{Tc}, \mathrm{Km}$ and $\mathrm{Cm}$, and those resistant to $\mathrm{Tc}, \mathrm{Sm}, \mathrm{Km}$ and $\mathrm{Cm}$, and also carrying hsII+ ${ }^{+}$. Again, the result can be explained in terms of the presence of two $\mathrm{R}$ factors in the original strain, one carrying resistance to $\mathrm{Tc}$ and to $\mathrm{Sm}$, and also carrying the hsII determinant, the other carrying resistance to Tc, $\mathrm{Km}$ and $\mathrm{Cm}$.

$T$ The $f$ character of the separated $R$ factors from $75-3(R 269)$ and $y_{5-3}(R 348)$. A number of $\mathrm{R}^{+}$strains have been shown to carry both an $f^{+}$and an $f^{-} \mathrm{R}$ factor, though the presence of the $f^{-} \mathrm{R}$ factor was masked by the $f^{+} \mathrm{R}$ factor when the strains were tested originally for their ability to plate the F-specific phage MS 2 (Romero \& Meynell, 1969). Since two $f^{+} \mathrm{R}$ factors do not co-exist stably (Watanabe et al. I964), it was pre- 
Table I. Properties of exconjugants obtained after mating $R^{+}$strains with strain $C 600$.

\begin{tabular}{|c|c|c|c|c|}
\hline \multicolumn{5}{|c|}{$\begin{array}{l}\text { An overnight culture of the } \mathrm{J} 5-3 \mathrm{R}^{+} \text {donor wa } \\
\text { an inclined rotor at } 37^{\circ} \text { for } 90 \mathrm{~min} \text {., then dilut } \\
\text { recipient and kept at } 37^{\circ} \text { for } 30 \mathrm{~min} \text {. This mat } \\
\text { in soft agar overlays on supplemented VB agar } \\
48 \mathrm{hr} \text {. Colonies were purified by stabbing on } \mathrm{t} \\
37^{\circ} \text { before replica-plating to determine drug re } \\
\text { by streaking colonies on Difco agar plates whi } \\
\text { grown on K, and incubated overnight at } 37^{\circ} \text {. }\end{array}$} \\
\hline \multirow{2}{*}{$\begin{array}{l}\mathrm{R} \text { factor and } \\
\text { determinants } \\
\text { carried }\end{array}$} & \multirow{2}{*}{$\begin{array}{l}\text { Drug } \\
\text { resistance } \\
\text { selected }\end{array}$} & \multirow[b]{2}{*}{$\begin{array}{l}\text { Determinants } \\
\text { found }{ }^{*} \dagger\end{array}$} & \multicolumn{2}{|c|}{ Nos. observed } \\
\hline & & & Expt. I & Expt. 2 \\
\hline \multirow[t]{4}{*}{$\begin{array}{l}\text { R269 } \\
\text { Tc Sm Su Km hsII }{ }^{+}\end{array}$} & $\mathrm{Tc}$ & $\begin{array}{l}\text { Tc Sm hsII } \\
\text { Tc Sm Km hsII }\end{array}$ & $\begin{array}{l}97 \\
30\end{array}$ & $\begin{array}{r}35 \\
117\end{array}$ \\
\hline & $\mathrm{Sm}$ & $\begin{array}{l}\text { Tc Sm hsII } \\
\text { Tc Sm Km hsII } \\
\text { Sm Km }\end{array}$ & $\begin{array}{l}15 \\
40 \\
15\end{array}$ & $\begin{array}{r}2 \\
46 \\
96\end{array}$ \\
\hline & $\mathrm{Su}$ & $\begin{array}{l}\text { Tc Sm Su hsII } \\
\text { Tc Sm Su Km hsII } \\
\text { Sm Su Km }\end{array}$ & $\begin{array}{r}0 \\
2 \\
128\end{array}$ & $\begin{array}{r}2 \\
39 \\
102\end{array}$ \\
\hline & $\mathrm{Km}$ & $\begin{array}{l}\text { Tc Sm Km hsII } \\
\text { Sm Km }\end{array}$ & $\begin{array}{r}25 \\
120\end{array}$ & $\begin{array}{l}36 \\
99\end{array}$ \\
\hline \multirow[t]{4}{*}{$\begin{array}{l}\mathrm{R} 348 \\
\mathrm{Tc} \mathrm{Sm} \mathrm{Km} \mathrm{Cm} \mathrm{hsII}\end{array}$} & Tc & $\begin{array}{l}\text { Tc Sm hsII } \\
\text { Tc Km Cm } \\
\text { Tc Sm Km Cm hsII }\end{array}$ & $\begin{array}{r}16 \\
97 \\
8\end{array}$ & $\begin{array}{r}112 \\
27 \\
2\end{array}$ \\
\hline & $\mathrm{Sm}$ & $\mathrm{Tc} \mathrm{Sm}$ & 75 & 68 \\
\hline & $\mathrm{Km}$ & $\begin{array}{l}\text { Tc Sm Km Cm hsII } \\
\text { Tc Km Cm }\end{array}$ & $\begin{array}{r}19 \\
109\end{array}$ & $\begin{array}{r}4 \\
33\end{array}$ \\
\hline & $\mathrm{Cm}$ & $\begin{array}{l}\text { Tc Km Cm } \\
\text { Tc Sm Km Cm hsII }\end{array}$ & $\begin{array}{r}123 \\
33\end{array}$ & $\begin{array}{r}5 I \\
3\end{array}$ \\
\hline
\end{tabular}

* At least 20 colonies of each tested for hsII where available.

$\dagger$ It is not possible to score Su resistance by replica-plating, hence Su resistance is not recorded for R 269, except where Su resistance was selected directly.

Table 2. Phage $M S 2$ plating and presumed $f i$ character of $F^{+} R^{+}$strains

$\begin{array}{cccccc}\begin{array}{c}\text { Parent } \\ \text { R factor }\end{array} & \begin{array}{c}\text { Drug resistances } \\ \text { present }\end{array} & \text { hsII } & \begin{array}{c}\text { MS 2 } \\ \text { plating* }\end{array} & \begin{array}{c}f \text { character } \\ \text { deduced }\end{array} & \begin{array}{c}\text { No. of } \\ \text { colonies }\end{array} \\ \text { R269 } & \text { Tc Sm Su } & + & + & - & 3 \\ \text { R 269 } & \text { Sm Su Km } & - & - & + & 6 \\ \text { R348 } & \text { Tc Sm } & + & + & - & 3 \\ \text { R 348 } & \text { Tc Cm Km } & - & - & + & 7\end{array}$

* MS 2 plating was determined by spotting $0.0 \mathrm{I} \mathrm{ml}$. of an MS 2 lysate on to the $\mathrm{F}^{+} \mathrm{R}^{+}$strain in soft agar on Difco agar plates.

sumed that the two strains $\mathrm{J} 5-3$ (R 269) and J 5-3 (R 348), had both harboured an $\mathrm{fi}^{+}$ and an $f^{-} \mathrm{R}$ factor. To test this assumption the presumed separated $\mathrm{R}$ factors were transferred by conjugation to $\mathrm{J}_{5-3} \mathrm{~F}^{+}$strain, which was then tested for lysis with the F-specific phage MS 2. The results are presented in Table 2. Lysis was abolished by the segregant of $\mathrm{R} 269$ carrying resistance to $\mathrm{Sm}, \mathrm{Su}$ and $\mathrm{Km}$, and similarly by the segregant of $\mathrm{R} 348$ carrying resistance to $\mathrm{Tc}, \mathrm{Km}$ and $\mathrm{Cm}$. Tests which showed a re- 
duced efficiency of plating of phage $\mathrm{T}_{3}$ (Schell et al. 1963 ) confirmed that $\mathrm{F}$ was still present and thus that these $\mathrm{R}$ factors were acting by preventing its expression, and were therefore $f^{+}$. The remaining two components of the original $\mathrm{R} 269$ and $\mathrm{R} 348$ factors, which carried the hsII ${ }^{+}$character, were both $f^{-}$.

There have been three previous reports of $\mathrm{R}$ factor associated host specificities. For two $f^{-} \mathrm{R}$ factors described by Watanabe et al. (1966), it had been possible to identify the host specificity since one of the R factors, R 15 , was made available for this purpose, and the host specificity found was hsII. Yoshikawa \& Akiba (1962) also found a host specificity associated with $f^{-} \mathrm{R}$ factors, while the third report (Molina, 1964) did not specify the $f i$ character nor give details of the host specificity. There remains, therefore, only one instance of an $\mathrm{fi}^{+} \mathbf{R}$ factor carrying host specificity determinants, this being the association of R I24 with the determinants for hsI, a host specificity distinct from hsII (Bannister, I969). It is possible that once again the $f^{+} \mathbf{R}$ I24 masks the presence of a second $f^{-} \mathbf{R}$ factor which carries the hsI determinants, since it is not unusual for an $f^{-} \mathrm{R}$ factor to be present in an apparently $f^{+}$strain (Romero \& Meynell, 1969). However, it has not been possible to separate hsI from the $f_{i}$ character and resistance to Tc, the only drug resistance carried by this $\mathrm{R}$ factor (Bannister, 1969 ).

This work was part of a Ph.D. thesis presented at the University of Edinburgh, and was carried out while the author was the recipient of an M.R.C. Scholarship for Training in Research Methods.

I wish to express my appreciation of the help given me by Dr S. W. Glover, particularly for his careful reading of the manuscript.

\section{REFERENCES}

APPLEYARD, R. K. (1954). Segregation of a new lysogenic type during growth of a doubly lysogenic strain derived from Escherichia coli K 12. Genetics, Princeton 39, 440,

Arber, M. \& Dussolx, D. (1962). Host specificity of DNA produced by Escherichia coli. I. Host controlled modification of bacteriophage $\lambda$. Journal of Molecular Biology 5, 16.

BANNISTER, D. (1969). Restriction and modification controlled by resistance transfer factors. Ph.D. thesis, Edinburgh University.

BANNISTER, D. (1970). Analysis of an $\mathrm{R}^{+}$strain carrying two $\mathrm{fi}^{-}$sex factors. Journal of General Microbiology 6r, 273.

BANNISTER, D. \& Glover, S. W. (I968). Restriction and modification of bacteriophages by $\mathrm{R}^{+}$strains of Escherichia coli KI2. Biochemical and Biophysical Research Communications 30, 755.

Bannister, D. \& Glover, S. W. (I970). The isolation and properties of non-restricting mutants of two different host specificities associated with drug resistance factors. Journal of General Microbiology 6r, 63 .

Clowes, R. C. \& Rowley, B. (1954). Some observations on linkage effects in genetic recombination in Escherichia coli KI2. Journal of General Microbiology II, 250.

Davis, J. M., Strauss, J. M. \& Sinsheimer, R. L. (1961). Bacteriophage MS 2: another RNA phage. Science, New York 134, 1427.

JACOB, F. \& Wollman, E. L. (1954). Étude génétique d'un bactériophage tempéré d'Escherichia coli: Le système génétique du bactériophage $\lambda$. Annales de Institut Pasteur, Paris 87, 653.

LuRIA, S. E. (1953). Host-induced modification of viruses. Cold Spring Harbour Symposia on Quantitative Biology 18, 237.

Meynell, E., Meynell, G. G. \& Datta, N. (I968). Phylogenetic relationships of drug-resistance factors and other transmissible plasmids. Bacteriological Reviews 32, 55.

Molina, A. M. (1964). Genetic elements with cytoplasmic location controlling drug and phage $\mathrm{TI}_{\mathrm{I}}$ resistance in Enterobacteriaceae. Giornale di Microbiologia 12, 107. 
Romero, E. \& MeYnell, E. (1969). Covert $f^{-}$R factors in $f^{+} \mathbf{R}^{+}$strains of bacteria. Journal of Bacteriology 97, 780 .

Schell, J., Glover, S. W., Stacey, K. A., Broda, P. M. A. \& Symonds, N. (1963). The restriction of phage $\mathrm{T}_{3}$ by certain strains of Escherichia coli. Genetical Research, 4, 483 .

WatanABE, T. (1963). Infective heredity of multiple drug resistance in bacteria. Bacteriological Reviews 27, 87.

Watanabe, T., Nishida, N., Ogata, C., Arai, T. \& Sato, S. (1964). Episome-mediated transfer of drug resistance in Enterobacteriaceae. VII. Two types of naturally occurring R factors. Journal of Bacteriology 88, 7I6.

Watanabe, T., Takano, T., Arai, T., Nishida, H. \& Sato, S. (I966). Episome-mediated transfer of drug resistance in Enterobacteriaceae. X. Restriction and modification of phages by $f-\mathbf{R}$ factors. Journal of Bacteriology 92, 477.

Yoshikawa, M. \& AkIBA, T. (I962). Studies on transferable drug resistance in bacteria. IV. Suppression of plaque formation of phages by the resistance factor. Japanese Journal of Microbiology 6, 121. 